\title{
The Steep Rise Of Gift Card Purchases By The Consumer Is Changing The Method Of Accounting And Reporting Of Gift Card Income By Corporate Retailers \\ Carla Feinson, Bethune-Cookman University
}

\begin{abstract}
The increasing popularity of gift card purchases by consumers and the corresponding increase in gift card sales in the retail industry has triggered changes in accounting disclosures and reporting requirements. The Financial Accounting Standards board, the Security and Exchange Commission and individual state legislatures have all begun to focused their attention on the various issues that are continually coming to the forefront as a result of the continuing rise in gift card transactions. The promulgations of these authoritative bodies have in turn affected the format and wording of the disclosures that are found in the annual reports or SEC filings of publicly held retail companies. An examination of 75 publicly traded retailers not only shows the similarities and differences of how gift card sales have affected disclosures but also how the very nature of gift card contracts and the ramifications of gift card sales has led to so many specific reporting and accounting difficulties.
\end{abstract}

\section{INTRODUCTION}

ift card sales reached 24.8 billion dollars in 2006-- a 34\% increase over 2005 (Fetterman, Mindy 2006). While the increasing sales of gift cards may at first appear to give a boost to the annual sales figures for the corporate retailer, this is in fact not the case. Gift Cards Sales are not recognized as revenue at the time of sale. Proceeds from gift card sales are considered unearned or deferred revenue and remain as liabilities until the holder redeems them for goods or services or until they expired or until they are considered to be unlikely to be redeemed by the holder. Therefore sales of gift cards in November or December will not result in income recognition until the gift card redemption which may not occur for several months or, perhaps, ever. As gift card sales increase they become a larger component of a company's financial life. And, as gift card sales and the related accounting and legal issues relating to those sales become a material factor in the financial statement user's decision making processes, additional financial disclosures are needed in order to fairly present the financial information of the company.

\section{METHODOLOGY}

In order to determine the current climate of gift card reporting, the author examined the most recent 2006 annual financial statements and/or SEC's (Security and Exchange Commission's) 10K annual filings of 75 retailers for all references to gift cards. (For a detail list of companies in the survey see the Appendix.) An excel spreadsheet was assembled with each quoted reference and then condensed into a more manageable spreadsheet which merged and collated similar references. The percentage of each like kind disclosure was calculated and the final table is presented here as Exhibit 1. 


\begin{tabular}{|c|c|c|c|c|}
\hline \multicolumn{3}{|c|}{ Exhibit 1 Summary of Gift Card Disclosures for 75 Retailers } & $\%$ of 75 & $\%$ of 41 \\
\hline 1 & No reference to gift card issues & 34 & $45.33 \%$ & NA \\
\hline 2 & Disclosures Relating to Deferred Income Recognition & $41 *$ & $54.67 \% *$ & $100 \% *$ \\
\hline 3 & Company records sale of gift cards as deferred revenue (and/or liability) & 30 & $40.00 \%$ & $73.17 \%$ \\
\hline 4 & Gift card revenue recognized as Net Sales when redeemed & 2 & $2.67 \%$ & $4.88 \%$ \\
\hline 5 & Gift card revenue recognized when gift card is redeemed & 32 & $42.67 \%$ & $78.05 \%$ \\
\hline 6 & Gift card revenue recognized as other income when gift card is redeemed & 4 & $5.33 \%$ & $9.76 \%$ \\
\hline 7 & $\begin{array}{l}\text { Amount of unredeemed gift card liability for current fiscal year and prior fiscal year } \\
\text { disclosed separately or combined with one or more other items }\end{array}$ & 20 & $26.67 \%$ & $48.78 \%$ \\
\hline 8 & Disclosures Relating to Breakage & $24 *$ & $32.00 \% *$ & $58.54 \% *$ \\
\hline 9 & Gift Card breakage is recognized based upon historical redemption patterns. & 18 & $24.00 \%$ & $43.90 \%$ \\
\hline 10 & Breakage recognized when Gift Card redemption considered remote & 18 & $24.00 \%$ & $43.90 \%$ \\
\hline 11 & Gift card redemption is considered remote after 24 months from issuance & 4 & $5.33 \%$ & $9.76 \%$ \\
\hline 12 & Gift card redemption is considered remote after 12 months from issuance & 3 & $4.00 \%$ & $7.32 \%$ \\
\hline 13 & Unredeemed Gift cards are written off after 60 months & 2 & $2.67 \%$ & $4.88 \%$ \\
\hline 14 & Gift Cards Expire after 24 months & 1 & $1.33 \%$ & $2.44 \%$ \\
\hline 15 & Gift card redemption is considered remote after 4 years from issuance & 1 & $1.33 \%$ & $2.44 \%$ \\
\hline 16 & Estimated value of breakage is recognized ratably as a proportion to actual redemptions & 4 & $5.33 \%$ & $9.76 \%$ \\
\hline 17 & Gift card breakage is amortized on a straight line basis & 2 & $2.67 \%$ & $4.88 \%$ \\
\hline 18 & $\begin{array}{l}\text { No breakage recognized yet In the process of analyzing based upon historic redemption } \\
\text { patterns and current laws }\end{array}$ & 1 & $1.33 \%$ & $2.44 \%$ \\
\hline 19 & Amount of current and prior fiscal year gift card breakage is disclosed & 7 & $9.33 \%$ & $17.03 \%$ \\
\hline 20 & $\begin{array}{l}\text { Current or prior fiscal year represents the first year that breakage is accounted for and } \\
\text { therefore the amount recorded includes breakage from all prior periods }\end{array}$ & 3 & $4.00 \%$ & $7.32 \%$ \\
\hline 21 & $\begin{array}{l}\text { Gift Card breakage recorded as a reduction in Selling, General \& Administrative } \\
\text { Expenses }\end{array}$ & 6 & $8.00 \%$ & $14.63 \%$ \\
\hline 22 & Gift Card breakage recorded as revenue and/or other operating income & 4 & $5.33 \%$ & $9.76 \%$ \\
\hline 23 & Gift Card breakage recorded Net Sales & 3 & $4.00 \%$ & $7.32 \%$ \\
\hline 24 & No expiration date & 12 & $16.00 \%$ & $29.27 \%$ \\
\hline 25 & $\begin{array}{l}\text { Actuarial analysis or redemption patterns. Adjusted breakage life down to } 4 \text { years from } \\
7 \text { change resulted in credit to SGA of } 12,400,000\end{array}$ & 1 & $1.33 \%$ & $2.44 \%$ \\
\hline 26 & $\begin{array}{l}\text { Company makes estimates based upon historical analysis of the relationship of } \\
\text { breakage to gift card sales based upon } 10 \text { years of data }\end{array}$ & 1 & $1.33 \%$ & $2.44 \%$ \\
\hline 27 & $\begin{array}{l}\text { Through February } 2,2007 \text {, the Company has not recorded any breakage income related } \\
\text { to its gift card program. The Company will continue to evaluate its current breakage } \\
\text { policy as it continues to gain more sufficient company-specific customer experience. }\end{array}$ & 1 & $1.33 \%$ & $2.44 \%$ \\
\hline 28 & $\begin{array}{l}\text { Gross profit also includes } \$ 1.8 \text { million, or } 20 \text { basis points, of unredeemed gift cards } \\
\text { recorded as revenue in fiscal } 2004 \text {, versus only } \$ 0.1 \text { million recorded as revenue in } \\
\text { fiscal } 2003 \text {. }\end{array}$ & 1 & $1.33 \%$ & $2.44 \%$ \\
\hline 29 & $\begin{array}{l}\text { Fiscal } 2006 \text { extraordinary gain included gift card breakage of } 6.1 \text { million referred to } \\
\text { twice (used once } 2.1 \text { million) }\end{array}$ & 1 & $1.33 \%$ & $2.44 \%$ \\
\hline 30 & Disclosures Relating to Deferred Income Recognition \&Breakage & NA & & \\
\hline 31 & $\begin{array}{l}\text { Gift card liability represents the amount of gift cards that have been issued but have not } \\
\text { been redeemed, net of estimated breakage. }\end{array}$ & 1 & $1.33 \%$ & $2.44 \%$ \\
\hline 32 & $\begin{array}{l}\text { Recognize estimated unredeemed gift card under the redemptive recognition method. } \\
\text { (This method records gift card breakage as additional sales on a proportional basis over } \\
\text { the redemption period based on historical redemption trends. Such adjustments are } \\
\text { included in net sales and operating income.Inventory) }\end{array}$ & 1 & $1.33 \%$ & $2.44 \%$ \\
\hline 33 & $\begin{array}{l}\text { If redemption is considered remote the liability for unredeemed gift cards will be } \\
\text { reversed }\end{array}$ & 1 & $1.33 \%$ & $2.44 \%$ \\
\hline 34 & $\begin{array}{l}\text { To the extent that future redemption patterns differ from those historically experienced, } \\
\text { significant variations in the recorded reserves may result }\end{array}$ & 1 & $1.33 \%$ & $2.44 \%$ \\
\hline 35 & $\begin{array}{l}\text { Disclosures Relating to Other Accounting Issues Caused by various Gift Card } \\
\text { Policies Including Deferred Income Recognition \&Breakage }\end{array}$ & NA & & \\
\hline 36 & Note on Contingencies includes Litigation disclosure relating to gift cards & 1 & $1.33 \%$ & $2.44 \%$ \\
\hline 37 & $\begin{array}{l}\text { Gift card Service Fee income included in other income. Fee charged where law allows. } \\
\text { Initiated after } 24 \text { months }\end{array}$ & 1 & $1.33 \%$ & $2.44 \%$ \\
\hline 38 & Gift Card Accounting triggered change in accounting method disclosure & 1 & $1.33 \%$ & $2.44 \%$ \\
\hline 39 & Related Party note relating to gift card sales & 1 & $1.33 \%$ & $2.44 \%$ \\
\hline
\end{tabular}


40 Company formed a subsidiary to handle all sales and liabilities associated with gift card Adjustment for transfer was credited to SGA

41 Restricted cash balance is linked to at least $25 \%$ of balance of unredeemed gift cards and store credits

42 During fiscal 2005, we recognized $\$ 1.3$ million as income from gift cards that are not expected to be redeemed based upon an extended period of dormancy. For the Disney Store, we act as an agent on behalf of a subsidiary of The Walt Disney Company for gift cards sold to customers. Therefore, we do not record a customer gift card liability for the Disney Store. However, we recognize a trade payable to Disney for the net purchase of Disney gift cards. Of the $\$ 1.3$ million adjustment, the Company estimates that approximately $\$ 1.0$ million relates to fiscal 2004 and prior. The Company did not restate prior years' financial statements since the impact was immaterial

43 A small and relatively stable percentage of gift cards will never be redeemed, referred to as "breakage." Estimated breakage revenue is recognized over a period of time in proportion to actual gift card redemptions and was immaterial in 2006, 2005 and 2004.

\section{Disclosures Relating to Escheatment Issues or Laws Affecting Gift Card Policies}

45 Escheatment issues disclosed and or state laws are referred to

46 If merchandise credits or gift cards are not redeemed over an extended period of time (approximately 3-5 years), the value of the merchandise credits or gift cards is generally remitted to the applicable jurisdiction in accordance with unclaimed property laws.

* Financial Reports and/or Sec filings had more than one disclosure in this category

$\begin{array}{ccc}1 & 1.33 \% & 2.44 \% \\ 1 & 1.33 \% & 2.44 \% \\ 1 & 1.33 \% & 2.44 \% \\ & & \\ & & \\ & & \\ & & \\ & & \\ & & \\ 1 & 1.33 \% & 2.44 \% \\ & & \\ 10 * & 13.33 \% * & 24.39 \% * \\ 10 & 13.33 \% & 24.39 \% \\ 1 & 1.33 \% & 2.44 \%\end{array}$

\section{DISCUSSION}

Of the 75 annual financial statements and/or SEC's (Security and Exchange Commission's) $10 \mathrm{~K}$ annual filings examined 34 or $45 \%$ (Exhibit 1 Line 1) did not have any disclosures relating to gift cards. Many, if not all of the 34 non-disclosing companies, do in fact sell gift cards to the general public. However, it is possible that the total dollar amount of gift card sales is below the threshold for what the individual retailer considers material for reporting purposes or SEC filing. Also many companies may still be uncertain as to how to proceed with gift card sales accounting and disclosures and may not as yet have a definitive policy in place relating to gift card activities.

As can be seen from the above examples, gift card transactions, has led to a variety of reporting disclosures and accounting methods. Several companies that report gift card information are still adjusting their policies and the related financial disclosures to suit their needs and the requirements of the accounting and legal environment. Of the 41 (Exhibit 1, Line2) retailers who did report information about gift card sales, many had multiple disclosures covering various related issues within their annual financial statement and/or $10 \mathrm{~K}$ filing.

Disclosures relating to unearned/deferred revenue recognition: Unearned/deferred revenue recognition disclosures are usually incorporated into the first note found after the presentation of the financial statements. This note is often labeled "Significant Accounting Policies". All companies following generally acceptable accounting principles (GAAP) must disclose to the users of financial information the acceptable accounting policies that they have chosen to use for gathering and reporting accounting information. The note on "Significant Accounting Policies" is usually very general and often includes references to the nature and description of the business, inventory costing methods, depreciation methods, advertising expense recognition, etc. Therefore revenue recognition issues relating to the handling of gift card sales will often appear first in this note.

Unearned or deferred income results when cash is received from a customer for goods or services that will be provided at some future period. In the case of a gift card -- no specific goods or services are described and there is significant uncertainty concerning the redemption process. The redemption may lead to full retail priced goods, discounted goods, or goods valued at less than cost. Thus the final profit realized by the gift card seller is completely undeterminable at the point of sales. Furthermore unlike some other unearned or deferred revenue agreements the owner of the gift card is often an unknown party. All 41 of the retailers who reported on gifts card sales (Exhibit 1, Line 2) disclosed one or more times in their annual reports and/or annual SEC filings their method of accounting for gift card sales. 
The recognition of earned income-- if any -- that will result from the gift card redemption pivots on the consumers' actions. It is a contingent event that is outside the control of the corporate retailer. Some gift cards will never be redeemed. They may be misplaced or lost or simply not represent a desirable purchase by the consumer. The handling of unredeemed gifts cards by the seller represents the most difficult aspect of gift card sales.

Disclosures relating to breakage: Breakage occurs when the holder of a gift card fails for some unknown reason to redeem the gift card. Breakage can be accounted for as income or as a reduction of an expense. Recognition of gift card breakage varies from retailer to retailer but the SEC's staff view (Schlosser, Pamela R, 2005) accepts three methods and these methods are also currently accepted by the AICPA, FASB, PCAOB and IASB.

- $\quad$ Breakage can be recognized based upon an analysis of historical redemption rates by the corporate retailer. For example: a calculation based upon a review of previous gift card sales may show that an average percentage of total annual gift card sales would never be redeemed. The corporate retailer would then apply this historical percentage each year to the total annual gift card sales for the period to determine the adjustment needed to recognize breakage for the reporting period. ("To use this method, the company will be required to reasonably and objectively estimate the gift card breakage as well as estimate the period of actual gift card redemption." (Price Waterhouse Coopers, 2006)

- Breakage can be recognized when there is no longer a legal obligation on the part of the retailer to honor the gift card.

- $\quad$ Breakage can be recognized when there is considered to be a remote possibility of redemption (usually a specific time period such as 1 year, 1.5 years, 2 years, etc.).

While most of the retailers who reported on gift card issues did refer to breakage (Exhibit 1, Line 8), there were many differences in the policies and methods used to handled breakage issues. Corporate retailers' breakage policies and the related effect of these policies on their disclosures are currently in flux. Policies relating to breakage are evolving and changing as state laws governing breakage issues change and catch up to the steep rise in consumer purchases (see below). Corporate retailers' breakage and non-redemption policies often include expiration dates and fee penalties for inactive gift cards. These restrictive policies facilitate the accounting process and the management of the costs associated with the problems surrounding the tracking and satisfaction required for the growing outstanding liability for unredeemed gift cards. However these policies exist at the expense of the consumer. The consumer who has already paid for future purchases will automatically lose the economic benefit of that payment if the time period for the purchases elapses. Consumer protection is the responsibility of the state.

Disclosures relating escheatment, unclaimed property and other state laws: Most states have escheatment laws that cover unclaimed or abandoned property. (National Conference of State Legislatures 2007).Unredeemed gift cards can qualify as unclaimed property and at least 39 states have laws addressing issues relating to unredeemed gift card monies. More and more states legislatures are enacting laws affecting gift card non-redemptions, fees and expiration dates. Several states (including Maryland, Illinois and Utah) have or are in the process of establishing laws which restrict or eliminate the use of expiration dates and/or dormancy fees on gift cards. State laws supersede, within the state, whatever the retailer's gift card contract may say if it is contrary to the state law. Escheatment and unclaimed property laws generally require retailers to forfeit any unearned gift card amounts over to the local state treasurer after a set period of time. While only 10 retailers in Exhibit 1 (Line 44) made disclosures relating to escheatment laws, it is probable that all of the retailers are affected by the laws in one or more of the states in which their business occurs.

The issues surrounding the levying of fees and penalties on unredeemed gift cards and the various escheatment laws existing through out the nation has already caused several retailers to change they policies and financial reporting disclosures with regard to expiration fees, cash management and breakage calculations.

Disclosures relating to other issues: By referring to Exhibit 1 (Lines 35 to 43), the impact of gift card sales has spawned disclosures that reveal how several retailers have decided to adjust corporate policies to accommodate the specific accounting problems that have arisen as a result of the increased complexity of gift card accounting. 
One retailer disclosed that gift card accounting triggered a change in accounting method. A change in accounting method requires the reporting company to retrospectively report all prior period accounting information currently disclosed as if the new method were in place all along. This requires that the comparative financial statements which show the previous period(s) Balance Sheet, Income Statement and Changes in Equity Statements be revised to reflect the impact of the changed method so that these statements can still be comparable even after the change to a new accounting method. This can be a costly and time consuming process especially if it also requires a change of income tax reporting to the IRS.

Exhibit 1 (Line 36) shows that at least one retailer is involved in litigation relating to gift card sales. Litigation requires a note that discusses the contingent nature of a lawsuit. Losses arises from litigation can not be readily determined until a judgment has been made. Exposure to the liabilities that may accompany gift card sales is an added cost and headache to retailers.

Exhibit 1 (Line 40 and Line 42) shows that at least two retailers have decided to establish a separate corporate entity whose sole function is to handle all accounting and legal reporting and responsibilities related to gift card sales. These corporate retailers formed a separate subsidiary company and transfer all activities relating to gift card activities to the subsidiary.

Exhibit 1 (Line 41) shows that at least one retailer has had to establish a restricted cash account where monies earmarked for payments relating to escheatment, unclaimed property and other gift card problems would be readily available when needed.

\section{CONCLUSION}

Clearly the increase in gift card sales by retailers indicates that gift card sales programs are a successful addition to the retailer's business plan. Gift card sales may enhance corporate profits and liquidity but as gift card purchases become more popular with the consumer, retailers will have to grapple more and more with the costs and special issues surrounding the these purchases. Gift card sales affect the retailer's accounting and reporting requirements as well as the required compliance with various state statutes. Accounting and reporting promulgations are currently evolving as the SEC and accounting authorities visit the issues arising from the sale of gift cards. The overseers of financial reporting rules must evaluate and determine the kinds of accounting problems that need to be handled by the reporting company. Problems that relate to the deferred or unearned income aspect of gift card sales may require retailers to account for and report on: changes in accounting methods; estimates for contingent loses; restrictions on assets; and/or adjustments regarding subsequent events. In addition, retailers will have to adjust to the changing legal restrictions governing gift card non-redemptions and breakage. As long as state legislatures continue to amend the laws covering gift card fees, penalties and expiration dates, the liability and responsibilities of retailers and the ensuing reporting and accounting issues will keep retailers scrambling to accommodate the needs and requirements of the financial environment.

\section{REFERENCES}

1. Fetterman, Mindy (2006, December 29). Gift cards change way retailers do business. USA Today, http://www.usatoday.com/money/industries/retail/2006-12-29-gift-card-usat_x.htm

2. $\quad$ National Conference of State Legislatures (2007, May 8). State Statutes http://www.ncsl.org/programs/banking/GiftCardsandCerts.htm

3. Price Waterhouse Coopers (2006, January). What We Heard at the SEC Conference. Retail \& Consumer Quick Brief! Volume 4, Issue 1. http://www.pwc.com/us/eng/retail/QuickBriefs_v4 1.pdf

4. Schlosser, Pamela R (2005, December 5). Statement by SEC Staff: Remarks Before the 2005 AICPA National Conference on Current SEC and PCAOB Developments. Office of the Chief Accountant. U.S. Securities and Exchange Commission. http://www.sec.gov/news/speech/spch120505ps.htm 


\section{APPENDIX}

\section{List Of Retail Companies Included In Table:}

Annual Reports for fiscal 2006: Acal plc, Advance Auto Parts, American Eagle Outfitters, Ann Taylor, Auto Nation, AutoZone, Barnes \& Noble Inc., Bed Bath \& Beyond Inc., Best Buy, Big Lots Inc., BJ's Wholesale Club, Blue Nile. BMHC, Books-A-Million Holding, Circuit City, Costco Wholesale, CSK Auto, CVS, Dollar Tree Stores, Family Dollar Stores, Foot Locker, Gander Mountain Company, Home Depot, Insight Enterprises, Kroger Company, Lithia Motors, Longs Drug Stores, Lowe's, Men's Wearhouse, OfficeMax, Pep Boys, Petsmart, RadioShack, Rite Aid, Ross Stores, Saks, Select Comfort, Sonic Automotive, Spartan Stores, Staples, Talbots, Target, The Children's Place Retail Stores, The Pantry, TJX, Trans World Entertainment, United Retail Group, WalMart Stores, Whole Foods Market, Williams-Sonoma, Wilsons The Leather Experts, Zale Corporation

Annual 10K filing for fiscal 2006: Abercrombie \& Fitch, Adtrans Group Limited, Alexon Group plc, Borders Group, Charming Shoppes, Charlotte Russe. Dollar General, Finlay Enterprises, Federated Department Stores, Goody's Family Clothing, Group 1 Automotive, Hastings Entertainment, JC Penney, Kohl's Department Stores, Nordstrom, Omnicare, Pathmark Stores, Payless Shoe Source, Ruddick, The Bon-Ton Stores Inc., Tiffany \& Co., Value Vision Media, Wet Seal

\section{NOTES}

